\title{
Efforts to Develop Social-Emotional Aspects in Showing Tolerance Using a Combination of Explicit Instruction Model and Cooperative Learning with Playing Method in Early Childhood Education Student's
}

\author{
Asniwati $^{1}$, Mayasari $^{2 *}$ \\ 1,2Department of Early Childhood Education, Universitas Lambung Mangkurat, Banjarmasin, Indonesia
}

\begin{tabular}{l|l}
\hline \multicolumn{1}{c|}{ A R T I C LE I N F O } & \multicolumn{1}{c}{ A B S T R A C T } \\
\hline $\begin{array}{l}\text { Received: 07-03-20I7 } \\
\text { Revised: 07-05-20I7 }\end{array}$ & $\begin{array}{l}\text { The result and process of learning of at early childhood education children are still } \\
\text { not in accordance with their age and expectation that faced by the low of social- } \\
\text { emotional development specifically on tolerance and cooperation in conducting } \\
\text { during various teaching and learning activities. In order to solve the problem, this } \\
\text { study used the combination of explicit instruction and cooperative learning model } \\
\text { with playing method. This research was conducted using qualitative approach with } \\
\text { Keywords: } \\
\text { Social-emotional, tolerance action research and three times learning class and using instrument to observe of } \\
\text { explicit instruction, } \\
\text { cooperative learning, } \\
\text { teacher and students' activities. The result indicates that the teacher and children } \\
\text { activities improved on the third learning with very good and very active criterion, and } \\
\text { children social-emotional aspect develop gradually as expected at the last learning. }\end{array}$ \\
\cline { 2 - 3 } & $\begin{array}{l}\text { C 2018 The Authors. Journal of K6, Education, and Management (j-K6EM). ISSN: 2580-2135. } \\
\text { Published by Graduated Program of Educational Management, Universitas Lambung } \\
\text { Mangkurat, Banjarmasin, Indonesia. This is an open access article under the open journal } \\
\text { systems 3. }\end{array}$ \\
\hline
\end{tabular}

*Author correspondence: Mayasari; E-mail: mayasari601@gmail.com 


\section{Introduction}

Education plays a central and important role in determining the quality of change and improvement of a nation. As the agent of change, education must be formulated and planned as an effort to develop the society potential according to the aspiration and demand of times.

Syarifuddin in Masitoh (20II) describes that in a broad sense, education takes place for anyone, anytime and anywhere. Education is not limited on formal education only, but it takes place from birth to the end of life. Education takes place in the family, school, and society.

The most interesting to observe in human is growth and development on a child that last since the period of conception until adolescence. Development is changes in cognitive biological and socio-emotional started from birth to the end of life. Development is defined as the increasing structure and function of the body that is more complex in the ability of gross and fine motion, talking or speaking, and socialization skill.

The foundation built in Early Childhood Education requires a strong structure, both the learning aspect in playing activity and development of child potential. The concept will be integrated if the educator is able to create an exciting stimulation program in the activity.

Therefore, an Early Childhood Education educator is required to design an interesting and challenging activity, implement enjoyable learning, able to observe and record student's growth process, and evaluate its conducted playing activity or learning program. Early childhood development is always called as golden age where all knowledge in this period is strongly affected by the habit and effective stimulus given including physical and motor development, cognitive, social emotional, language, and religion and moral values. At the stage of 3-6 years old, there are some characteristics that are different from the age of baby.

Act Number 20 of 2003 on National Education System Article I point I4 states that Early Childhood Education is a coaching effort aimed at children from birth up to the age of six conducted through the provision of educational stimulus to assist growth and development physically and spiritually so that children have a readiness in entering further education Learning Program Development Guidelines in Kindergarten (Minister of Education Regulation, 2013).

From the statement above we can conduct the education to the generation appropriately and as planned in every learning process, to develop their potential actively, intelligently, and have spiritual values.

Child development is running continuously, which means that the achieved development level at one stage is expected to increase both quantitatively and qualitatively in the next stage. In addition, each child is unique, child development is different from each other as it is affected by internal factors, but child development still follows the general patterns. For the children to achieve an optimum development level, parent and adult involvement are required to provide a comprehensive and integrated stimulus covering education, nurture, health, nutrition, and protection given consistently by habituation (Regulation of Minister of Education, 2009).

It is started by providing a directed education from an early age until the children can understand the knowledge. Learning can take place anywhere and anytime in accordance with the potential and social needs as the basic a life in the surrounding community.

Social-emotional development of early childhood is also considered important since it deals with all child development aspects. There are several aspects of social-emotional development that are needed to be developed in early childhood. Some of them are learning to socialize, cooperate, and tolerate. It is also important to develop children skills in interacting with peers and teach the acceptable attitude in the surrounding environment.

Social meaning is understood as an effort to introduce children to other people outside themselves and their environment, as well as the mutual effect of various life aspects, both in the form of individual or group. In sociological study, social process and describes it as follows: interaction means is taken into consideration if 
individual and social group meet each other and determine the system and form this relationship, or what will happen if there are changes that disturb the existing patterns (Soekanto, 20II).

Individual social development follows a pattern, namely a sequence of ordered social behavior, in which the pattern is the same for every child normally where some psychologists assume that social development begins when a child was born in the world, this is proven when a child is crying as an effort to contact others (Sholeh, 2005).

The social-emotional aspect is closely related to a process of somebody in responding an event and expressing it through facial expression, body movement, and words (Purna \& Kinasih, 2015). The way a person responds to an event from the environment depends on the problem-solving skills that have already been learned that make children react differently when they face the environmental challenges whether they are enthusiastic, happy, calm or even run away because they feel afraid (Purna \& Kinasih, 2015).

Tolerance can be implemented by giving children the equal treatment to pray in accordance with their respective religion and belief, and by teaching them about the importance of togetherness, such as playing, eating, and learning together, in fact togetherness will encourage tolerance and mutual respect (Fadillah, 2016).

Based on result of the observation of the child learning outcomes at Sultan Early Childhood Education in Banjarmasin, showed that in two years ago, social development of children specifically on tolerance, still lack of socialemotional skill in tolerating, that not fulfilled the appropriate development achievement.

This is due to the lack of good social skills in terms of tolerance and cooperation when doing various activities. Before and after the learning process children are less concerned to others and get less attention by others. This is seen in some children who do not bring stationery such as color pencil and so on during the teaching and learning process and then borrow to other children who carry more stationery. But the other child refuses to share and lend his/hers. When children are resting and playing, they just play alone and do not want to play together or engrossed with their own activities. In addition, they also stay away from other friends, so that the expected social development is not good enough for the future development of children.

In the development period when children have not understood yet the social environment demand on them, they will be unable to react according to the expectation of social environment. Even if they understand, they still face an obstacle to adjust that expectation. This is because the children are less able to capture the attitude and condition of other people, so they are less able to tolerate others.

Most social life is affected by the status or condition of family social life in the society. The society will not view the child as an independent child, but they see them in a whole context of the child's family or "whose child" is he/she. Indirectly, in the child social interaction, the society and its group will consider the norms prevailing in the family (Sunarto, 2008).

Based on the problems that occurred, it's interesting to conduct a research to explore learning activity that able to develop socialemotional aspect of children in terms of tolerance and cooperate with friends using a combination of Explicit Instruction and cooperative learning model with playing method. The using of these methods is expected to build tolerance and understanding, and awareness. It is also expected to teach children to work diligently so that it becomes a habit in their social-emotional aspect development. In addition, the playing method is one of the teacher strategies to achieve learning objective as a demand and essential needs for kindergarten children. Through playing, children can satisfy the need of motor, cognitive, creativity, language, emotional, social, value, and attitude development.

In the explicit instruction model, the teacher demonstrated before performed activities and guided the children during the activity. While in cooperative learning model, the teacher taught the children in groups. Last, in the playing method was used to achieve appropriate process of child development in playing while learning or vice versa with the three combination.

Based on the background above, the researchers create a learning solution that is set to be able to develop social attitude that can be understood well directly. So, the researchers conduct a research entitled "Effort to Develop Social- 
Emotional Aspects in Showing Tolerance Using a Combination of Explicit Instruction Model and Cooperative Learning with Playing Method in Group B at Sulthan Early Childhood Education, Banjarmasin."

This Classroom Activity Research aims to determine: (I) Teacher Activity during learning, (2) Child activity while learning, (3) Result of child skills in learning activity to develop socialemotional aspect in showing tolerance.

\section{Methodology}

A good methodology should bring the researcher to achieve of the objective (Dalle, 2010; Dalle et al., 20I7; Derlina et al., 2018). We used qualitative approach with CAR type. We collected the data, improved and developed the social-emotional aspect development in activity process in the classroom. This was in line with Kunandar (20I2) that CAR is an action research conducted aiming to improve the learning quality in classroom. For further information about the research method/approach, method is defined as a scientific way to obtain a valid data aiming to find, develop and prove a certain knowledge, so that it could be used to understand, solve, and anticipate problems in education (Darwati, 20I I).

In CAR, the researchers/teachers can see the learning practice alone or conduct a research with other teachers on students in terms of interaction aspects in the learning process. In CAR, teacher could analyze and synthesize reflectively on what has been done in the classroom. By using CAR, the educator could improve the learning practice to be more effective. Furthermore, the CAR was seen, perceived, and internalized to bring up the question whether the learning practices that have been done have high effectiveness. In short, CAR is a research where the problem appeared, and it is felt directly by the teacher concerned in the classroom. So, it is difficult to be justified if there is an assumption that the problem in classroom action research is identified from the perception or assurance (Arikunto, 20II).

To solve the real problems that occur in the classroom then it is necessary to improve the teacher professionalism and foster academic culture among teachers. Learning practice quality improvement occurred continuously as the society develop rapidly. Education relevance increase is achieved through the learning process improvement. In CAR was conducted at least in 2 cycles. The stages of each cycle consist of: planning, action implementation, observation and reflection in this study was planned with learning.

According to Kunandar (2012), a good data is the valid and reliable data. It is obtained from a valid and reliable instrument. Valid instrument is an instrument that measures what should be measured. Reliable instrument is a consistent instrument to measure what should be measured. Both were used to develop the ability of socialemotional aspect based on the competence and indicator to be achieved.

The next step was to analyze the qualitative data collected from the observation of teacher and student activities during the learning. It was conducted through the initial, main, and final activity by implementing the explicit instruction and cooperative learning model. Teacher activity was said to be success if the teacher observation assessment result was successfully implemented according to the selected model and with a score of 30 by $80 \%$ percentages with good category at minimum. Child activity was said successful if the classical observation in learning activity achieved $82 \%$ percentage with active category at minimum. In the quantitative data on the number or individual children development score, most children were active with a minimum percentage of $80 \%$ at minimum and the children also developed as expected.

\section{Results and Discussion}

In the activity of teacher, children, and children skills in showing tolerance, children socialemotional development increases successfully in each meeting. From here, it can be interpreted that there is a link between the three factors in the observation. If the teacher activities can be carried out in accordance with the steps and implemented according to the needs of the child, it will be able to make the learning process more conditioned and optimal. This mainly affects the activities that children do in following the teaching-learning process provided by teachers, to encourage children to become more active and develop as expected. 
The teacher activities improve due to teacher accuracy in selecting and defining combination of explicit instruction and cooperative learning model with playing method. In addition, it is also due to the reflection on each cycle in the form of improvement made by teacher on teacher activity. The way teacher patiently helps the children in case of difficulties, the way teacher guides, directs and motivates the children also affect the good result. This is in line with the use of explicit instruction and cooperative learning model by using playing method where teacher gives guidance and motivation to the children. Sanjaya (2006) said that teacher has an important role in the learning process. Teacher who can become a student's friend helps the children to socialize with others faster (Sujiono, 2009). Teacher can help children who lack confidence by making them learn how to play with their friends. So, teachers in kindergarten should not just sit in the corner of the classroom, but they must also participate in the game played by the children.

In relation to this issue, every teacher should be an expert that mastering and loving their respective study field. Each teacher must have a competence in explaining generally to the children according to the topic/subject matter learned by the children. In addition, Susanto (20II) said that teacher should have certain such as patient, affectionate, caring, friendly, tolerance, empathy, loving, accepting children as they are, fair, giving children freedom and creating familiarity with children. Personality is important as teacher becomes a model and stimulus in student character who will imitate, see, and follow what is conducted by the teacher. Therefore, it is very important for teacher and educator of early childhood to have a calm, fun and strong character.

Based on the data analysis, the researcher finds there is an increasing in children activity, in the kindergarten learning activity the children are demanded actively in the activity and the teacher only acts as a guide and directs the children in that activity.

The discussion and result of this study are in accordance with the expert opinion, as stated by Piaget in Yuliani (2012), children build their knowledge through interaction with the environment. Children are not a passive object who receive knowledge, but they actively organize their experience into a complex mental structure.
Mursid (2015) said that educator should direct children to be an active learner. A creatively designed education will lead to active learning. Aqib (2013) said that learning process takes place naturally where the student works and experiences things, so it is not only about transferring knowledge from teacher to student. Djamarah (20II) said that some methods can activate many students including experimental methods, demonstrations, problem solving, discussion, discovery, inquiry and assignment.

This research is in line with a research conducted by Dahliyani (2015), states that child activity in cycle I obtains $50 \%$ with good enough category then increases in cycle II by obtaining $90 \%$ with very active category that can be said that every development will succeed if it is conducted properly to the potential and problem solution faced by children.

Aqib (20II) said that children should be given the opportunity to learn optimally, anytime and anywhere. Implementation is realized by providing an opportunity for children to hear, see, observe and touch the object around. Morever, Mariyana et al. (2010) also emphasize that the more often a person performs learning activities, his/her behavior will change better, and this happens either as a direct result of the act or learning experience, as well as indirect or indirect impact of various activities.

Based on the data analysis in previous section regarding social-emotional skill result. The researcher discovers an increase in the result of religious and moral value of children in imitating praying movement. The research was conducted through a combination of demonstration method and picture and picture model with a flannel board media, performed in two cycles with three meetings where $94 \%$ of children developed successfully or I7 out of I8 children. It is supported by Idris (20I4) state a fun teacher will be able to raise student learning spirit through the delivery of subject matter and able to make it looks interesting and impressive so that students are happy and not forced to study.

This study also shows an increase in third learning with the previously described criteria in which the result of child development in learning process should be based on teacher who is able to modify learning activity and give innovation and solution. 
According to Dimyati and Mudjiono (2009), to obtain an optimal learning result, a good learning process is required. By using a combination of explicit instruction and cooperative learning model with playing method, it can organize the learning well so that the children social ability that has been achieved can continue to develop. Therefore, the activities performed in early childhood should be directed to improve children skills. Learning in kindergarten should emphasize both the play-oriented and development-oriented learning. This research also used to play method but with different aspects, so that the result will be more optimal and efficient. Montessory in Yuliani (2012) states that children learn through sensory and sense. The five senses are the gateway to various knowledge into human brain. Due to their crucial role, then all the five senses must have the opportunity to develop in accordance with their function.

By various combinations that have been tried by the previous researchers, it shows that the research using the benefit of these model and method have been proven. They are able to improve the skills of research subjects. Therefore, the researchers add innovation by using three different combinations than the previous research that only use two solutions.

\section{Conclussion}

Based on the study and discussion above, it can be concluded as follow (I) Teacher activity increased with very good category; (2) Child activity increased with percentage of $93 \%$; and (3) Result of social aspect development reached the expected success indicator.

\section{Acknowledgment}

The writer expresses the gratitude to the head of preschool and elementary school teacher education program and the head of early childhood education program that have supported this research, as well as the lecturers, staff and other parties involved in assisting the research to the completion of this article. The writer also expresses the gratitude to the principal, teachers, and children at Sulthan Early Childhood Education, so this research could be conducted properly. And the last is for our families who always give support both material and non-material. May God the Almighty gives bless to all the involved parties

\section{References}

Ahmadi, A., \& Nunawarah, S. (2005). Psikologi perkembnagan. Jakarta: Rineka Cipta

Al-Tabany, T. (2015). Desain pengembangan pembelajaran tematik. Jakarta: Prenada Media Group.

Aqib, Z. (2013). Model-model, media, dan strategi pembelajaran kontekstual (inovatif). Bandung: Yrama Widya.

Arikunto, S. (20I0). Penelitian tindakan. Yogyakarta: Adtya Media.

Arikunto, S. (2012). Prosuder penelitian suatu pendekatan praktik. Jakarta: Rineka Cipta.

Dalle, J. (20I0). Metodologi umum penyelidikan reka bentuk bertokok penilaian dalaman dan luaran: Kajian kes sistem pendaftaran siswa Indonesia. Thesis PhD Universiti Utara Malaysia.

Dalle, J., Hadi, S., Baharuddin., \& Hayati, N. (20I7). The Development of Interactive Multimedia Learning Pyramid and Prism for Junior High School Using Macromedia Authorware. The Turkish Online Journal of Educational Technology, November. 7I4-72I.

Derlina., Dalle, J., Hadi, S., Mutalib, A.A., \& Sumantri, C. (2018). Signaling Principles in Interactive Learning Media through Expert's Walkthrough. Turkish Online Journal of Distance Education (TOJDE). I9(4), I47-I62

Dimyati., \& Mudjiono. (2009). Belajar dan pembelajaran. Jakarta: Rineka Cipta.

Kunandar. (2012). Penelitian tindakan kelas. Jakarta: Rajagrafindo Persada.

Masitoh. (20II). Strategi pembelajaran tk. Jakarta: Universitas Terbuka

Sistem Pendidikan Nasional. Undang-Undang Nomor 20 Tahun 2003

Sujiono, Y.Y. (2012). Konsep dasar pendidikan anak usia dini. Jakarta: Indeks. 